\title{
Persistence of Maternally-Derived Antibody in Selected Group of Chicks to Fowl Pox Virus
}

\author{
AHM Taslima Akhter ${ }^{1}$, M Shahidur Rahman Khan ${ }^{1 *}$,Narayan Chandra Paul ${ }^{1}$, Abdul Kafi ${ }^{1}$, Niraj Kanti Shil ${ }^{2}$ and \\ Mahbubul Pratik Siddique \\ ${ }^{1}$ Department of Microbiology \& Hygiene, Faculty of Veterinary Science, Bangladesh Agricultural University (BAU), Mymensingh 2202, Bangladesh, \\ ${ }^{2}$ Department of Medicine, Faculty of Veterinary Science, Bangladesh Agricultural University (BAU), Mymensingh 2202, Bangladesh
}

[Received 18 February 2008; Accepted 14 June 2008]

\begin{abstract}
The investigation was conducted to determine the persistence of maternally derived antibody as well as its influence on vaccination programme against fowl pox infection. A total of 60-day-old chicks divided into four groups such as A, B, C, D. Chicks of Group A and B were used for the detection of persistence of maternally derived antibody which are originated from fowl pox virus-vaccinated and non-vaccinated parent stock respectively. For the detection of antibody level after vaccination with live fowl pox and pigeon pox virus vaccine following two vaccination schedules, chicks of group $C$ and $D$ were subdivided into group $C_{1}, C_{2}$ and $D_{1}, D_{2}$ originating from fowl pox virus vaccinated and non-vaccinated parent stock. It is found that maternally derived antibody passed over from the parents to progeny chicks and remains protective level for the chick of group A until day 4 of age and the chicks of group B which are originated from non-vaccinated parent stock remains protective level only at day 1 . Chicks of subgroup $C_{2}$ and $D_{2}$ produce higher antibody titre, which were boosted at 15 days interval. Frequent out breaks of fowl pox infection in chicks of Bangladesh either from fowl pox virus-vaccinated and non-vaccinated origin may be avoided by vaccination with pigeon pox virus vaccine at day 5 followed by a secondary vaccination with fowl pox virus vaccine at day 21 .
\end{abstract}

Keywords: Maternally-derived antibody (MDA), Chicks, Fowl pox (FP), Fowl pox virus (FPV)

\section{Introduction}

Fowl pox (FP) is a slow spreading viral disease of chickens particularly in chicks up to 4 to 6 weeks of age characterized by a pronounced transitory inflammatory process and resulting in hyperplasia of the epidermis and feather follicles. The disease gradually terminates to form scabs with desquamation of degenerated epithelium ${ }^{1}$. In some cases, diphtheritic membranes or proliferative lesions may develop in the mouth pharynx and oesophagus ${ }^{2}$.

Fowl pox is caused by fowl pox virus (FPV), a double stranded DNA virus under the genus Avipox of the family Poxviridae. Each member of Avipox virus is host specific as well as antigenically significant, yet a cross-relationship has been demonstrated among the species ${ }^{3-4}$.

Fowl pox is an important viral disease of mortality as high as $60-70 \%$ per incident has been reported with large number of incident per year in Bangladesh ${ }^{5}$. Fowl pox virus (FPV) vaccine and pigeon pox virus (PPV) vaccine have been routinely used for more than half a century to prevent fowl pox in commercial poultry in areas where the disease is endemic ${ }^{6}$. In Bangladesh, FPV vaccine used in pullets and adult birds at the age of 3-5 weeks of age, which is manufactured by the Directorate of Livestock
Services (DLS). The vaccine is not used in chicks for its pathogenicity though it can produce solid long lasting immunity. The PPV vaccine is therefore recommended by DLS for the prevention of fowl pox in chicks aged at day 1 to day 5, which produce immunity for about 6 month, but this vaccine is not still used in field trial. Immune response in chickens against fowl pox produced by PPV vaccine was studied in other countries ${ }^{7}$. Fowl pox is frequently reported in previously vaccinated flock from the every corner of the country causing serious problem to poultry raisers.

This paper describes the persistence of maternally derived antibody (MDA) in chicks as well as to determine the influence of MDA on the production of antibody following fowl pox virus and pigeon pox virus vaccine administered to chicks.

\section{Materials and Methods}

Scabs or nodules of fowl pox appearing on natural out break were collected aseptically and kept in screw capped vials containing $50 \%$ buffered glycerine during the study period. The materials were carried to the laboratory and were preserved at $-20^{\circ} \mathrm{C}$ and propagated by inoculating 10-day-old embryonated chicken eggs through chorioallantoic membrane (CAM) route. The CAM with discrete or confluent growth of pocks were selected and processed for further use.

*Corresponding author:

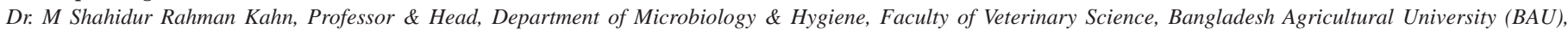
Mymensingh 2202, Bangladesh

Tel (Office): (091) 55695-7, Ext 2383; Cell: 01717 171329; E-mail: msrkhan001@yahoo.com 
Thirty-day-old white leg horn (WLH) and Sonali breed (SB) chicks originated from fowl pox virus (FPV) vaccinated parent stock were collected from poultry farm of Bangladesh Agricultural University (BAU), Mymensingh, and another group of 30-day-old chicks of local breed originated from FPV non-vaccinated parent stock were collected from the nearby village.

In order to determine the persistence of maternally-derived antibody (MDA) in chicks they were further divided as Group A (FPV vaccinated parents) and Group B (FPV non-vaccinated parents) each containing 15 chicks. Collection of blood was carried out from all the chicks at day 1, 4, 7, 10, 13, 16, 19, 22, 25, 28, 31 and 34 of age.

To determine the influence of MDA on vaccination programme against FPV infection, chicks of FPV vaccinated and FPV non-vaccinated parent stock were divided into two group $\mathrm{C}$ and D respectively each with remaining 15 chicks. Group $C$ and D were again subdivided in to six groups, namely, $\mathrm{C}_{1}, \mathrm{C}_{2}, \mathrm{C}_{3}, \mathrm{D}_{1}, \mathrm{D}_{2}$ and $D_{3}$. Subgroup $C_{1}$ and $D_{1}$ were primed with $P P V$ vaccine at day 5 and boosted with FPV vaccine at day 14 and blood was collected for the preparation of sera at day 7,14 and 21 age of postvaccination. Similarly, subgroup $C_{2}$ and $D_{2}$ were used for primary vaccination with PPV vaccine at day 5 and secondary vaccination with FPV vaccine at day 21 and blood was collected same as scheduled for previous groups. Group $\mathrm{C}_{3}$ and $\mathrm{D}_{3}$ were used as non-vaccinated control group.

All the sera samples were subjected to passive haemagglutination (PHA) test for the determination of antibody titre. The test was followed as per method described by Tripathy et al. ${ }^{8}$. Antigens (fowl pox virus) are coupled to chemically modified erythrocytes (sheep erythrocyte) and then antigen-coated erythrocytes readily react with specific antibodies and results in haemagglutination. Briefly $10 \mathrm{ml}$ of sensitized sheep red blood cells (SRBC) were prepared by the mixing of $1.5 \mathrm{ml}$ of $2.5 \%$ suspension of tannic acid treated cells with $0.5 \mathrm{ml}$ of 1:10 dilution of fowl pox virus suspension and PBS and incubated at $37^{\circ} \mathrm{C}$ for 30 min finally diluted with $1 \%$ normal rabbit serum diluents. An amount of $25 \mu \mathrm{l}$ of PBS was first poured in each well up to $9^{\text {th }}$ well of horizontal row of microtitre plate. The equal amount of test scrum was added in the $1^{\text {st }}$ well. Two-fold dilutions of serum ranging from 1:2 to 1:512 were made. Then a volume of $25 \mu \mathrm{l}$ of $0.5 \%$ fowl pox virus sensitized SRBC was added in each of the eight wells. Proper control in three horizontal rows was also maintained. The plates were kept at room temperature for 4 to $5 \mathrm{~h}$. The agglutination results were recorded by deposition of diffuse thin layer of clumping of RBC on the bottom of the well. The end point was determined by observing the highest dilution at which cells were agglutinated.

\section{Results and Discussion}

The present study was conducted to study the persistence of MDA in chicks as well as to study the antibody production to fowl pox virus (FPV) and pigeon pox virus (PPV) vaccine for the determination of the influence of maternally-derived antibody (MDA).

It was observed that maternally-derived antibody (MDA) was higher at the age of day $1(57.60 \pm 8.38)$ for FPV vaccinated parent stock and $35.33 \pm 4.98$ for FPV non-vaccinated parent stock, which was significantly lower than active immunized group and declined to a negligible level $(\leq 4 \pm 0)$ at day 16 for the former and day 13 for the later group (Table 1). The decay of MDA is approximately linear and day old chicks contain high levels of MDA, which gradually decline below positive level within 10-15 days of age ${ }^{9}$. Daroshoke and Belistkaya reported that the haemagglutination (HA) titre 40 was considered indicative of an adequate protective immunity ${ }^{10}$. In present study, it was observed that MDA levels in FPV vaccinated parent stock started to declined below its protective levels after 4 days and persisted up to day 13 and FPV non-vaccinated parent stock started to decline below its protective levels after day 1 and persisted at day 10 .

Table 1. Comparative maternally-derived antibody (MDA) titre of the chicks from day 1 to day 34 using passive haemagglutination (PHA) test

\begin{tabular}{lcc}
\hline $\begin{array}{l}\text { Age of bird } \\
\text { (Day) }\end{array}$ & \multicolumn{2}{c}{ MDA titre (Mean \pm SE) } \\
\cline { 2 - 3 } 1 & Group A & Group B \\
4 & $57.60 \pm 8.38$ & $35.33 \pm 4.98$ \\
7 & $38.40 \pm 5.13$ & $21.87 \pm 2.64$ \\
10 & $21.87 \pm 2.97$ & $14.93 \pm 2.05$ \\
13 & $11.73 \pm 1.26$ & $7.47 \pm 1.02$ \\
16 & $7.47 \pm 1.02$ & $\leq 4 \pm 0$ \\
19 & $\leq 4 \pm 0$ & $\leq 4 \pm 0$ \\
22 & $\leq 4 \pm 0$ & $\leq 4 \pm 0$ \\
25 & $\leq 4 \pm 0$ & $\leq 4 \pm 0$ \\
28 & $\leq 4 \pm 0$ & $\leq 4 \pm 0$ \\
31 & $\leq 4 \pm 0$ & $\leq 4 \pm 0$ \\
34 & $\leq 4 \pm 0$ & $\leq 4 \pm 0$ \\
\hline
\end{tabular}

Group A: Birds of vaccinated parent stock to FPV vaccine; Group B: Birds of non-vaccinated parent stock to FPV vaccine; FPV = Fowl pox virus; $\leq=$ Less than or equal to; $\mathrm{SE}=$ Standard error.

Table 2 and 3 represent the influence of MDA on immunity to PPV and FPV vaccination following different vaccination schedule in chicks originated from FPV vaccinated and non vaccinated parent stock. The highest antibody titre level from subgroup $\mathrm{C}_{1}$ of FPV vaccinated and $\mathrm{D}_{1}$ of FPV non-vaccinated parent stock were 153.6 $\pm 74.64,179.20 \pm 31.35$ respectively after 21 days of postvaccination period (Table 2). Subgroup $\mathrm{C}_{2}$ of FPV vaccinated and $\mathrm{D}_{2}$ of FPV non-vaccinated parent stock had a titre of $243.20 \pm$ 76.80 and $281.60 \pm 85$ after same periods of post-vaccination (Table 3). From the above findings it is concluded that chicks giving booster dose at day 21 of age showed higher passive haemagglutination (PHA) titre than chicks giving booster dose at day 14 of age. The results of this investigation are in agreement 
with those of Siddique et al. ${ }^{11}$ who observed that the PHA titre was found to be increased gradually during booster dosing at $8^{\text {th }}$ and $14^{\text {th }}$ weeks and highest PHA titre was 384 observed at $15^{\text {th }}$ weeks. Mathews ${ }^{12}$ reported that antiserum of fowl pox inhibited the haemagglutination (HA) of both fowl pox and pigeon pox viruses. Saini et al. ${ }^{13}$ observed that the geometric mean PHA titre showed a slow rise after first vaccination and resulted secondary vaccination cause rapid increase of PHA titre.

Table 2. Antibody titre in chicks after primary vaccination with pigeon pox virus (PPV) vaccine at day 5 followed by secondary vaccination with fowl pox virus (FPV) vaccine at day 14

\begin{tabular}{|c|c|c|c|c|}
\hline \multirow[t]{2}{*}{ Group } & \multirow{2}{*}{$\begin{array}{c}\text { Serial No. } \\
\text { of bird }\end{array}$} & \multicolumn{3}{|c|}{ Post-vaccination PHA titre after } \\
\hline & & 7 days & 14 days & 21 days \\
\hline \multirow[t]{5}{*}{$\mathrm{C}_{1}$} & 1 & 128 & 256 & 256 \\
\hline & 2 & 32 & 256 & 128 \\
\hline & 3 & 64 & 128 & 128 \\
\hline & 4 & 64 & 64 & 64 \\
\hline & 5 & 128 & 64 & 128 \\
\hline \multicolumn{2}{|c|}{$\begin{array}{c}\text { Mean PHA } \\
\text { titre } \pm S E\end{array}$} & $83.20 \pm 19.20$ & $140.80 \pm 31.35$ & $153.6 \pm 74.64$ \\
\hline \multirow[t]{5}{*}{$\mathrm{D}_{1}$} & 1 & 64 & 128 & 256 \\
\hline & 2 & 128 & 128 & 256 \\
\hline & 3 & 128 & 128 & 128 \\
\hline & 4 & 64 & 256 & 128 \\
\hline & 5 & 64 & 256 & 64 \\
\hline \multicolumn{2}{|c|}{$\begin{array}{c}\text { Mean PHA } \\
\text { titre } \pm \text { SE }\end{array}$} & $89.60 \pm 15.67$ & $166.40 \pm 38.40$ & $179.20 \pm 31.35$ \\
\hline
\end{tabular}

Subgroup $\mathrm{C}_{1}$ : Birds of vaccinated parent stock to FPV vaccine; Subgroup $\mathrm{D}_{1}$ : Birds of non-vaccinated parent stock to $\mathrm{FPV}$ vaccine; $\mathrm{FPV}=$ Fowl pox virus; PHA: Passive haemagglutination; $\mathrm{SE}=$ Standard error.

Table 3. Antibody titre in chicks after primary vaccination with pigeon pox virus (PPV) vaccine at day 5 followed by secondary vaccination with fowl pox virus (FPV) vaccine at day 21

\begin{tabular}{|c|c|c|c|c|}
\hline \multirow[t]{2}{*}{ Group } & \multirow{2}{*}{$\begin{array}{c}\text { Serial No. } \\
\text { of bird }\end{array}$} & \multicolumn{3}{|c|}{ Post-vaccination PHA titre after } \\
\hline & & 7 days & 14 days & 21 days \\
\hline \multirow{5}{*}{$\mathrm{C}_{2}$} & 1 & 32 & 256 & 256 \\
\hline & 2 & 64 & 256 & 128 \\
\hline & 3 & 32 & 512 & 64 \\
\hline & 4 & 32 & 128 & 128 \\
\hline & 5 & 64 & 64 & 64 \\
\hline \multicolumn{2}{|c|}{$\begin{array}{c}\text { Mean PHA } \\
\text { titre } \pm \text { SE }\end{array}$} & $51.20 \pm 7.84$ & $128.03 \pm 35.05$ & $243.20 \pm 76.80$ \\
\hline \multirow[t]{5}{*}{$\mathrm{D}_{2}$} & 1 & 32 & 256 & 128 \\
\hline & 2 & 64 & 512 & 256 \\
\hline & 3 & 32 & 128 & 128 \\
\hline & 4 & 32 & 512 & 64 \\
\hline & 5 & 64 & 512 & 256 \\
\hline \multicolumn{2}{|c|}{$\begin{array}{c}\text { Mean PHA } \\
\text { titre } \pm \text { SE }\end{array}$} & $51.20 \pm 84$ & $166.40 \pm 38.40$ & $281.60 \pm 85.00$ \\
\hline
\end{tabular}

Subgroup $\mathrm{C}_{2}$ : Birds of vaccinated parent stock to FPV vaccine; Subgroup $\mathrm{D}_{2}$ : Birds of non-vaccinated parent stock to FPV vaccine; FPV = Fowl pox virus; PHA: Passive haemagglutination; $\mathrm{SE}=$ Standard error.
Results of the present study recommend that, maternally-derived antibody (MDA) may not protect chicks originating from FPVvaccinated parent stock for more than 5 days of age while there from FPV non-vaccinated parent stock for one day only. MDA might interfere with antibody production in vaccinated birds. PPV vaccine produces low antibody titre which may be rapidly increased following a secondary vaccination with FPV. Frequent outbreaks of FP in chicks in Bangladesh either from FPV vaccinated or non-vaccinated parent stock may be avoided by vaccination with PPV vaccine at day 5 of age of which followed by secondary (booster) vaccination with FPV.

\section{References}

1. Sandhu TS \& Leibovitz L. 1997. Duck virus enteritis (duck plague). In Diseases of Poultry (Calnek W, Barnes HJ, Beard CW, McDougald LR \& Saif YM), $10^{\text {th }}$ edn, pp 675-683. Iowa State University Press, Ames, Iowa.

2. Tripathy DN \& Cunningham CH. 1984. Avian pox. In Diseases of Poultry (Hofstad MS, Barnes HJ, Calnek BW, Reid WM \& Yoder HW Jr eds), $8^{\text {th }}$ edn, pp 524-534. Iowa State University Press, Ames, Iowa.

3. Cunningham CH. 1972. Avian pox. In Diseases of Poultry (Hofstad MS, Calnk BW, Helmbotdt CF, Reid WM \& Yoder Jr HW eds), $6^{\text {th }}$ edn, pp 707-724. Iowa State University Press, Ames, Iowa.

4. Cunningham CH. 1974. Avian pox. In Diseases of Poultry (Hofstad MS, Calnk BW, Helmbotdt CF, Reid WM \& Yoder HW Jr eds), $7^{\text {th }}$ edn, pp 597-609. Iowa State University Press, Ames, Iowa.

5. Siddiky MNA, Amin MM, Amin MA \& Suman MSR. 2004. Efficacy of experimentally developed pigeon pox vaccine against fowl pox. Bangladesh Vet. 21(2): 92-96.

6. Singh P, Kim TJ \& Tripathy DN. 2000. Re-emerging fowlpox: Evaluation of isolates from vaccinated flocks. Avian Pathol. 29(5): 449-455.

7. Tripathy DN, Hanson LE \& Killinger AH. 1981. Poxviruses of veterinary importance: Diagnosis of infections. In Comparative Diagnosis of Viral Diseases (Kurstak E \& Kurstak C eds), Vol 3, Chapter 6, pp 267-346. Academic Press, New York.

8. Tripathy DN, Hanson LE \& Myers WL. 1970. Passive haemagglutination test with fowl pox virus. Avian Dis. 14: 29-38.

9. Natour AI, Ward MQ, Saif LA, Stwart-Brown B \& Keck LD. 1988. Effect of levels of maternally derived antibodies on protection against in IBDS. Avian Dis. 48: 172-182.

10. Doroshke IN \& Belistakya LA. 1969. Assay of post-vaccinational immunity to fowl pox. Veterinariya Moscow. 6: 25.

11. Siddique B, Rahman MB, Amin MM \& Rahman MM. 1997. Antibody titres in chicks following pigeon pox virus inoculation. Bangladesh Vet. 14(1-2): 12-14.

12. Mathews REF. 1979. Classification and nomenclature of viruses. Intervirology. 12:160-164.

13. Saini SS, Sodhi SS, Maiti KN \& Sharma SN. 1990. Combined oral vaccination against Newcastle disease and fowl pox. Indian J Anim Sci. 60(4): 387-389. 